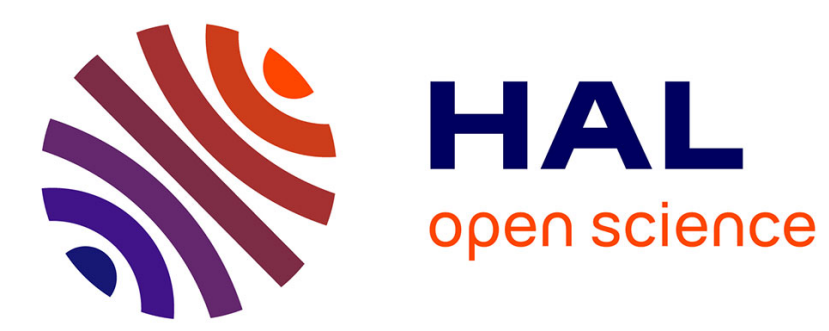

\title{
Historians vs. geographers: divergent uses of the ethnic name Turdetania in the Greek and Roman tradition
}

Pierre Moret

\section{To cite this version:}

Pierre Moret. Historians vs. geographers: divergent uses of the ethnic name Turdetania in the Greek and Roman tradition. G. Cruz Andreotti. Roman Turdetania, Brill, pp.13-33, 2019, 9789004382978. 10.1163/9789004382978_003. hal-01991225

\section{HAL Id: hal-01991225 \\ https://hal.science/hal-01991225}

Submitted on 5 Jan 2021

HAL is a multi-disciplinary open access archive for the deposit and dissemination of scientific research documents, whether they are published or not. The documents may come from teaching and research institutions in France or abroad, or from public or private research centers.
L'archive ouverte pluridisciplinaire HAL, est destinée au dépôt et à la diffusion de documents scientifiques de niveau recherche, publiés ou non, émanant des établissements d'enseignement et de recherche français ou étrangers, des laboratoires publics ou privés. 


\title{
Roman Turdetania
}

\author{
Romanization, Identity and Socio-Cultural \\ Interaction in the South of the Iberian Peninsula \\ between the 4th and ist Centuries $B C E$
}

Edited by

Gonzalo Cruz Andreotti

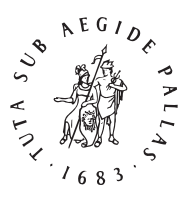

B R I L L

LEIDEN | BOSTON

For use by the Author only | ( 2019 Koninklijke Brill NV 


\section{Contents}

Preface: Spanish Turdetania, a Case Study for Shared Identities VII Gonzalo Cruz Andreotti

List of Figures and Tables XVII

Notes on Contributors $\mathrm{xx}$

$1 \quad$ Strabo and the Invention of Turdetania $\quad 1$

Gonzalo Cruz Andreotti

2 Historians vs. Geographers: Divergent Uses of the Ethnic Name Turdetania in the Greek and Roman Tradition $\quad 13$

Pierre Moret

3 The City as a Structural Element in Turdetanian Identity in the Work of Strabo 34

Encarnación Castro-Páez

4 Deconstructing 'Turdetanian Culture': Identities, Territories and Archaeology 46

Francisco José García Fernández

$5 \quad$ Ethnic and Cultural Identity among Punic Communities in Iberia 70 Eduardo Ferrer Albelda

6 Carthaginians in Turdetania: Carthaginian Presence in Iberia before 237 BCE 89

Ruth Pliego Vázquez

$7 \quad$ Tyrian Connections: Evolving Identities in the Punic West 108 Manuel Álvarez Martí-Aguilar

8 Unraveling the Western Phoenicians under Roman Rule: Identity, Heterogeneity and Dynamic Boundaries 130

Francisco Machuca Prieto

For use by the Author only | (c 2019 Koninklijke Brill NV 
9 Across the Looking Glass: Ethno-Cultural Identities in Southern Hispania through Coinage 148

Bartolomé Mora Serrano

10 The Economy and Romanization of Hispania Ulterior (125-25 BCE): The Role of the Italians 164

Enrique García Vargas

11 Epilogue: A New Paradigm for Romanization? 186

Gonzalo Cruz Andreotti

Bibliography 191

Index of Geographical Names 240

Index Locorum 248

Index of Personal or Ethnics Names, and Conceptual Terms 252

For use by the Author only | ( 2019 Koninklijke Brill NV 


\title{
Historians vs. Geographers: Divergent Uses of the Ethnic Name Turdetania in the Greek and Roman Tradition
}

\author{
Pierre Moret
}

The ancient geographic names Turdetania and Turdetani suffered great displacements and changes in meaning throughout their history.* They are first mentioned by Cato, who located them in central Iberia, reappearing later with Strabo in the Guadalquivir Valley and finally with Ptolemy in southern Portugal. A first clue to unravelling this instability may be found in their etymology, for Turdetania and Turdetani are Roman creations, as revealed by their suffixes, ${ }^{1}$ and not indigenous names transcribed into Latin. From this standpoint, the reasons for these changes are not only due to different chronological phases in the geographical discovery of Iberia, but also, as will be seen ahead, to the use given to these names by different authors.

Traditional scholarship minimized and overlooked contradictions in the literary sources because it aimed at ascribing the different communities mentioned in the sources with clearly defined locations on an ethnographic map of ancient Hispania. According to historical geographers of the beginning of the twentieth century, Strabo was the accepted source for the location of Turdetania, placing it in the Guadalquivir Valley, in the middle of Baetica. At the end of the twentieth century, archaeology based itself on this assumption to name an archaeological culture, which developed in the lower Guadalquivir during the Late Iron Age. However, when considering the history of this geographical concept, contradictions in the sources are just as important or revealing as their similarities. It is not a question of deciding who was closer

* This paper forms part of three research projects: 'Ethnic identities in southern Spain: Rise and Evolution in Antiquity 7th-2nd centuries BCE)' (HUM 03482), funded by the Council for Innovation, Science and Enterprise of the regional government of Andalusia, 'Ethnic and Political-Civic identity in Roman Spain: The Case of the Turdetania-Baetica' (HAR2012-32588), and 'Ancient Geography and Historiography: Space Representation and Transmission of Knowledge' (HAR2o16-76o98-C2-1-P), funded by the Ministry of Economics and Competitiveness of Spain.

All translations from greek and latin texts in this paper are the author's.

1 Faust 1966, 21-27.

(C) KONINKLIJKE BRILL NV, LEIDEN, 2019 | DOI:10.1163/9789004382978_003 
to the indigenous reality, Livy, Appian, Strabo, Pliny or Ptolemy. Such a search is condemned to fail because the creators of the ethnonym and subsequent users of the word never envisioned the criteria we deem necessary to define a culture or ethnic group. Our goal here is different: we seek to identify historically determining factors, which may be literary or ideological, in order to explain the metamorphosis of the concept 'Turdetania', from a Greek and Roman perspective.

\section{Historians and their Different 'Turdetanias'}

Generally, the starting point for any reflection on the meaning of a name referring to a community found on the periphery of the ancient world is the data given by geographers, because they are usually more coherent and detailed than the information provided by historians. The reverse order will be followed here, simply because this is one of the few cases in which there is a specific historical context for the birth of the choronym Turdetania, namely the official report by Cato, when he finished his command in Hispania.

\subsection{Cato and Livy}

Livy tells us that, in order to declare war on Saguntum in 219 BCE, Hannibal used as a pretext the conflict existing between the city and various neighbouring peoples (cum finitimis), although he only mentions one of them, the Turdetani (21.6.1). ${ }^{2}$ They are cited once again by Livy in 214, when, at the hands of the Romans, 'the Turdetani, who had brought about the war between Saguntum and Carthage, were reduced to subjection and sold as slaves; their city was utterly destroyed' (24.42.11). It may be deduced from this epilogue that the Turdetani only possessed one city, and that, as a population, they were numerically not very large, for they could be sold as slaves in their totality. They are mentioned for the last time in a speech pronounced in 205 by the Saguntine ambassadors before the Roman senate (28.39.8-12). They recalled with satisfaction that the city of these 'ancestral enemies' had been destroyed. It is hereby confirmed that the Turdetani in Livy's Books $21-28$ were a small community of eastern Iberia, structured around one city. It is worth mentioning that the narration of Appian on the same events (Hisp. 10) identifies the enemies of Saguntum with another name: Torbolêtes.

2 Polybius also refers to this local conflict, although briefly and without providing names (3.15.8). 
The names Turdetani and Turdetania appear twice again in the part of Livy's work that has been preserved. During the Battle of Ilipa, in 206 BCE, Attenes, king of the Turdetani, switched sides with his troops, abandoning the Carthaginians (28.15.14-15). Unfortunately, the sentence lacks any sort of topographical indication locating the provenance of these Turdetani.

Finally, in chapters $17^{-20}$ of Book 24, Livy narrates the campaign of Cato and his commanders against some Turdetani or Turduli (he uses both terms indifferently, sometimes only a few lines apart) in a region called Turdetania. This campaign began with a combined operation of the praetor P. Manlius, from Citerior, and Ap. Claudius Nero, from Ulterior, who joined Cato, in order to penetrate Turdetania. The Turdetani had secured reinforcements from Celtiberian mercenaries, who camped nearby (ch. 19.2). Livy tells us besides that these Celtiberians had left most of their equipment at a certain distance of the camps, in an oppidum called Seguntia (19.10). After a series of confusing diplomatic and military manoeuvres, Cato, abruptly and unexpectedly, withdrew in the direction of the Ebro Valley, in order to launch operations against other communities between the Ebro River and the Pyrenees (19.11 ff.). This story is completed by a passage found in the preceding book and by fragments from Cato himself. At the end of Book 33, Livy mentions an oppidum Turda (44.4), in a chapter narrating the attack launched in 196 вСЕ by Q. Minucius Thermus, praetor at the time in command of Citerior. In two fragments from the speech De consulatu suo, dated c. 191/19о вСЕ, Cato tells of his march in Turtam, 'towards Turta', sometime during the campaign of $195 .{ }^{3}$ This Turta and the oppidum Turda from Book 33 are probably the same city, an eponym for the Turdetani. ${ }^{4}$

In sum, Turdetani and Turdetania appear in the work of Livy in three different historical contexts: between 219 and 205 BCE in relation to Saguntum, constituting only one city; in $206 \mathrm{BCE}$, as part of the indigenous contingents taking part in the Battle of Ilipa, in the Guadalquivir Valley, although in this case, only the name of the king, Attenes, is known, and not the geographical origin; and in 195 BCE, during Cato's campaign south of the Ebro - on this occasion the Turdetani were a much larger group, maintaining close links with the Celtiberians. The assumption that it was the same people in the three episodes implies grave incongruences. The most serious (although not the one most frequently discussed by scholars) is the presumed virtual annihilation of the Turdetani in

3 Fr. 29 and 30 Sblendorio (Cugusi and Sblendorio 2001, 272): Cato says he moves forward, towards Turta, in aid of the army of Manlius.

4 The consonantal variation in the Latin transcription, Turta/Turda, may be caused by peculiarities in Iberian phonology (Faust 1966, 22-23). 
214 BCE. Although their city had been destroyed and all of their men had been sold into slavery, they appear twenty years later as a regional power and one of the most resistant adversaries encountered by Cato in Hispania.

There has been no lack of proposals by modern historians for the resolution of these contradictions. ${ }^{5}$ It is commonly assumed that the name given by Livy to the neighbours of the Saguntines is not the correct one, due to an involuntary mistake, confusion, or a voluntary substitution. ${ }^{6}$ As for the Turdetania in Book 34, most authors think that the battle took place in the Guadalquivir Valley, according to the geographical delimitation of the Turdetanian territory found in Strabo and Ptolemy, and that Cato moved thereafter to the northern Meseta, as he assaulted a town named Seguntia that has been identified with Sigüenza, Segontia Arevacorum in Pliny's lists $(\mathrm{NH} 3.27) .{ }^{7}$ However, another five Segontia or Seguntia may be found in Hispania. ${ }^{8}$ This name derives from the Celtic root sego-, which belongs to the semantic field related to victory. ${ }^{9}$ It is one of the most common toponymic elements among Celtic cities in Hispania, therefore, it is very possible that early in the second century все there existed other Seguntiae, which were not recorded in imperial written sources.

The question may be approached from another perspective, as suggested by Robert Knapp in an underappreciated paper. Throughout the entirety of his preserved work, Livy never uses the words Turdetania, Turdetani or Turduli to refer to the inhabitants of the Guadalquivir Valley or the Punic area of southern Iberia, ${ }^{10}$ whether in general descriptions or military accounts. The only names used in these instances, relating to historical contexts in southern Iberia, more specifically in the Baetis Valley, are Tartesii (23.26.5 ff.), Baeturia (33.21.8, 39.30.1) and Baetica (38.2.15). Although this may appear shocking at first, the truth is that Turdetania was not used by annalists or historians of the Second Punic War to designate the region, which was later identified with this name by Strabo.

On the other hand, there are strong indications that the homonymy of 218 and 195 BCE was the result of an intervention by Livy. ${ }^{11}$ When narrating the

Bibliography on the topic is extensive. Basic orientations in Astin 1978, 29 and 41; Knapp 1980; Uroz Sáez 1982; García Fernández 2003, 78-79; García Riaza 2006, 83-86.

6 For a detailed account on the hypotheses concerning the genesis of Turdetania in the environs of Saguntum, see Uroz Sáez 1982; García Fernández 2003; Moret 2011.

7 Schulten 1935, 188-90, followed by various authors, cited by García Riaza 2006, 84 .

$8 \quad$ Tovar $1989,347,365,375$ and 413.

9 Delamarre 2003, 269.

$10 \quad$ Knapp 1980, 49-51.

11 From this point onwards, my analysis diverges from Knapp (1980), for this author proposes in fine the identification between Turda and Turbula. 
conquest of Hispania, Livy did not simply summarize or paraphrase his sources. He resorted to all kinds of literary resources (simplifications, omissions, emphasis on determined characters ${ }^{12}$ or scenes), in order to present events in Hispania the most straightforward way possible, limiting the use of strange names, which were confusing and difficult to memorize. He adapted and simplified in his own way the ethnic map used by his annalistic sources, omitting certain names and merging others. This is what may have happened with the root Turd-, found in Cato, and the element Turb- or Torb- from Appian's Torbolêtes. Livy would have kept the only similar name in use during his time: Turdetani. It is not an isolated case: the same procedure of forcefully creating homonyms is sensed in north-eastern Hispania, between the Ausetani of Plana de Vic and lower Aragon. ${ }^{13}$

The only thing that may be said of the root Turb- or Torb-is that it is probably indigenous in origin, with a lexical parallel found in the Iberian epigraphy of northern Catalonia. ${ }^{14}$ As for the location of the Torbolêtes, the close similarity between this name and the place name Tourboula, mentioned by Ptolemy (2.6.60), cannot be a coincidence, firstly because they are both hapax, and secondly because, in Ptolemy's map, Tourboula is placed relatively close to Saguntum, at the juncture between the two main mountain ranges in Citerior: Idubeda and Orospeda (Figure 2.4). This representation of Iberia's orography helps explain a phrase found in Polybius, referring to Saguntum, which lies on the seaward foot of the range of mountains connecting Iberia and Celtiberia' (3.17.2). Tourboula is located precisely in the middle of the mountains mentioned by Polybius, which cannot be a coincidence. The topographical information collected by Ptolemy derives almost certainly from a source in which Tourboula was the capital of a homonym community ${ }^{15}$ in the vicinity of Saguntum.

The case of the Turdetani in Book 34 is very different. The form of the ethnonym is confirmed, as seen previously, by the reference to an oppidum Turda at the end of Book 33 and a place called Turta in two fragments of Cato. On the other hand, the use of the name Turdetani in a comedy by Plautus, ${ }^{16}$ staged for

12 This is the case, for example, of Indibilis and Mandonius, which Livy portrays differently from Polybius (cf. Moret 1997).

13 Cf. Benavente et al. 2003, 243.

14 Moncunill Martí 2015, 79: turba in an inscription, which was probably funerary, in Les Corts (Empúries).

15 The ending -êtes is a Greek suffix recorded in the composition of place names of the time of the Second Punic War (Faust1966, 34-38).

16 Captivi vv. 162-63. It belongs to a list of ethnonyms used in culinary puns: Pistorenses/ pistor (baker), Placentini/placentum (cake), Turdetani/turdus (thrush), etc. 
the first time between $195^{-190 ~} \mathrm{BCE},{ }^{17}$ proves that it was Cato who, returning to Rome, introduced the Latinized name. It was created to designate one of the peoples he claimed to have subdued in Hispania, awarding it fleeting popularity, which had not yet passed when Plautus wrote the Captivi. Therefore, both the name of the city, Turta/Turda, and the name of the corresponding community, the Turdetani, were first transmitted by Cato.

Where to situate the Turdetani from Turta/Turda? As mentioned previously, the majority of scholars do not hesitate in locating the territory in the Guadalquivir Valley, as described by Strabo. However, this location in southern Hispania, in the midst of the Ulterior province, presents significant difficulties. Firstly, let us not forget, this was the most urbanized region in Hispania - the future Baetica - where names were already known for a dozen cities that were already very developed before the arrival of Rome: Castulo, Iliturgi, Obulco, Carmo, Asta, etc. Turta, as a capital, would logically occupy a superior rank to all of these cities, although no other trace of its existence is to be found in the sources dealing with southern Iberia, nor in the epigraphy of Baetica.

Secondly, the geopolitical and historical context of Iberia in 195 BCE, when Cato arrived in Hispania, was particularly complex for the Romans, who were penned in their coastal bases after the revolt of numerous communities. The territories, which they still controlled - the coast of Catalonia, the lower basin of the Ebro, the coast of Valencia, the area of Carthago Nova, Gades and a part of the lower Guadalquivir - were separated from each other by wide regions which had become hostile due to the rebellions of 197 вСE. In such circumstances, the mission of the governors in Hispania during that decade consisted in re-establishing and maintaining the territorial continuity between Citerior and Ulterior through the strategic axis Tarragona-Saguntum-Castulo-Gades, which demanded great efforts in the intermediate area of the saltus Castulonensis, a region which remained insecure until the end of the Republic. ${ }^{18}$ They also had to control the axis Carthago Nova-Castulo, connected by the Segura and the Guadiana Menor rivers. Once this strategic line was controlled, they had to expand progressively throughout the Guadiana Basin, in Oretanian territory, and later throughout the Tajo Basin, in Carpetania.

This prudent strategy becomes evident in the military operations undertaken during the years following Cato's campaign (Figure 2.1). In the brief reports, transmitted by Livy, for the years 194-19о вСЕ, all of the identified

17 Franko 1995, 169.

18 Spranger 1958, 101-108; Sillières 1990, 261-274, 549 and 567; Cadiou 2008, 418-420.

For use by the Author only | (c 2019 Koninklijke Brill NV 


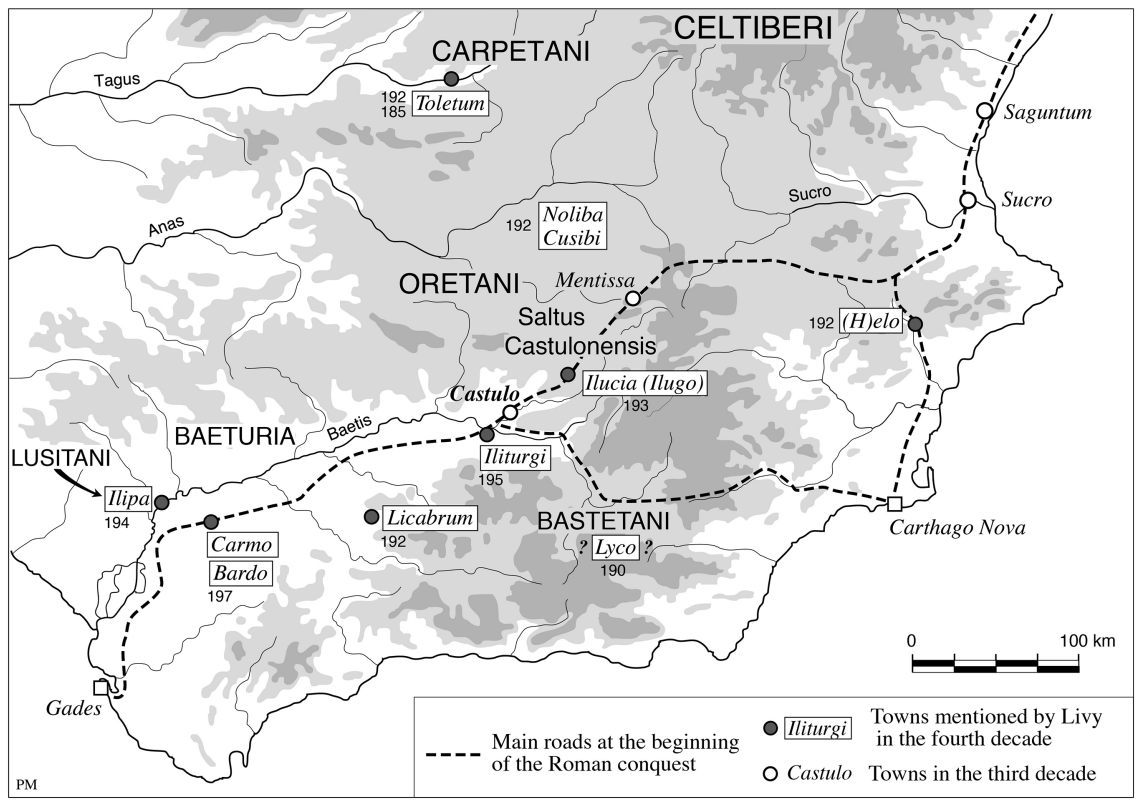

FIGURE 2.1 Military operations south of the Ebro in the years 197-19o, according to Livy. AFTER MORET 2011, MODIFIED.

cities are located along the itinerary Sucro-Castulo-Cádiz, except Toletum (Figure 2.2). ${ }^{19}$ For several years, the Roman generals concentrated their efforts along this vital communication route, in order to avoid incursions and choke revolts, in the core of the territories conquered by Scipio ten years before. No doubt, it was also in this region that Cato confronted the Turdetani. Is it possible to be more precise? Cato's Turdetania was not a great region, rich in natural resources, as would be later the Turdetania of Strabo. It was a territory defined according to a city called Turda or Turta. It could have been located in the upper Guadalquivir Basin, or even in the saltus Castulonensis, between Castulo and Saetabi. In the absence of a reliable place name, ${ }^{20}$ the only two elements which could be considered in identifying its location are the military movements of the Roman armies and Livy's reference to bordering territories.

19 Livy $35.1 .1 ; 35.1 .11 ; 35.7 .7 ; 35.7 .8 ; 35.22 .6-7 ; 35.22 .5 ; 37.46 .7$. Commentaries on the questioned cases in Moret 2011.

20 To my knowledge, there is no other name in the written sources or inscriptions, after Cato, which may be related to Turda/Turta.

For use by the Author only | (c 2019 Koninklijke Brill NV 


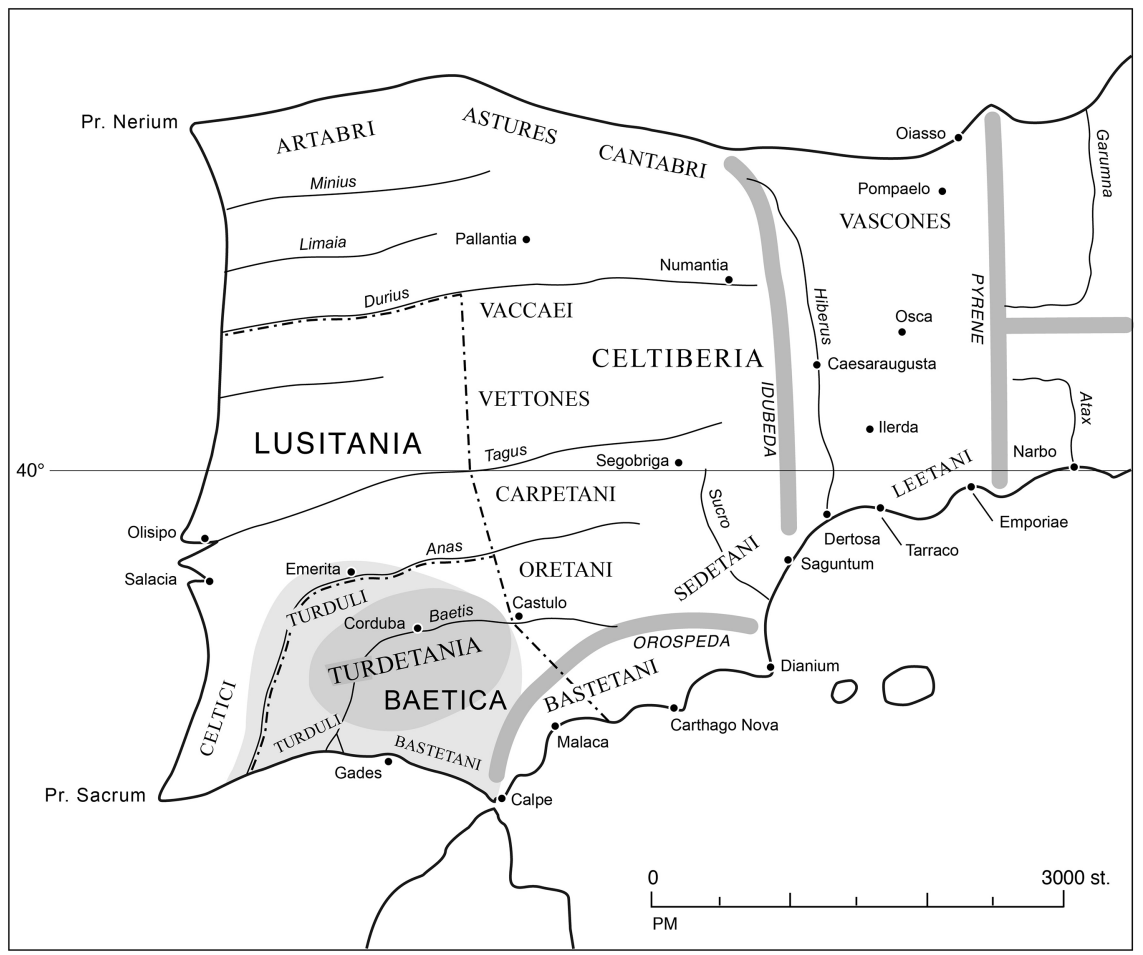

FIGURE 2.2 Turdetania in Strabo's Iberia.

SHAPE OF IBERIA AS IN MORET 2015; LIMITS OF LUSITANIA, FOLLOWING 3.4.20.

In the early moments of conquest, the movement of an army from the Ebro to the heart of the Baetis Valley could take over three weeks. ${ }^{21}$ However, the narration of the military movements of Cato and his commander Manlius from chapter 16 in Book 34 does not portray a long and enduring expedition. Cato does not seem to have any difficulty at all in passing from the Ebro territory to Turdetania and vice versa, according to the needs of the moment. On the other hand, Livy clearly states that Nero's troops, stationed until then in Ulterior, were transferred to join Manlius, when the latter decided to attack the Turdetani (ch. 17.1). If the territory of the Turdetani had been located in the Baetis Valley, it would be reasonable to suggest that Livy would have inverted the roles of Manlius and Nero, as argued by R. Knapp. ${ }^{22}$ If the troops sent by

\footnotetext{
21 Traveling at an iustum iter of $25 \mathrm{~km}$ per day (Cadiou 2008, 427).

22 1980, 50. This author also observes that Nero, the governor of Ulterior, sent part of his troops to Turdetania, but did not go with them (ibid. 53). This means Turdetania was outside his jurisdiction.
}

For use by the Author only | (c 2019 Koninklijke Brill NV 
Nero moved away from their bases in Ulterior and Manlius moved away from the Ebro Valley, leaving Cato behind, it follows that the Turdetani were located in an intermediate area, between the Júcar and upper Guadalquivir rivers.

On the other hand, the only geographical reference provided by Livy places the Turdetani as neighbours of the Celtiberians. This is deduced from chapter 19, in which military operations begin in Turdetania, near the camps of the Turdetani and their 'mercenary' neighbours, the Celtiberians. ${ }^{23}$ After a few skirmishes and confusing negotiations, 'when the consul failed to draw the enemy into battle, he first sent a few light-armed cohorts out to ravage the fields of a region hitherto unattacked, then, hearing that the baggage and equipment of the Celtiberians was all at Seguntia, he proceeded to attack that town' (ch. 19.9-10). The fact that Cato moved towards Seguntia with only a few troops and without baggage, clearly indicates that Turdetania bordered Celtiberia, and that Seguntia, the operational base of the Celtiberians, was relatively near the frontier between both territories. This fact alone should suffice to end the debate on a location in the mid and lower Guadalquivir Valley, strengthening the possibility of a location in the southern Meseta, perhaps in the area of the saltus Castulonensis (Figure 2.1). Celtiberia began immediately to the north of this area, in Segobriga, ${ }^{24}$ caput Celtiberiae (Pliny NH 3.25).

Lastly, the only indigenous names showing certain similarities with Turdetania, and particularly with Cato's Turta, are anthroponyms from the Ebro Valley: Turtumelis, ${ }^{25}$ Turtunaz and Turtunta, ${ }^{26}$ all three originating from the same root Turtun-. The base may be Iberian, ${ }^{27}$ although a possible adscription to Celtiberia should not be completely ruled out, if linking the word to Tortonda, a current place name from the eastern Meseta. ${ }^{28}$ All things considered, the name is closer to the northern Iberian or Celtiberian spheres than to the ethnic and linguistic sphere of Baetica.

In sum, Turdetani is a name created, or first brought to Rome, by Cato, for his triumph in 194 BCE. It is mentioned in Plautus' Captivi shortly after, indicating that the ethnonym was used in some sort of official speech or account

23 The term used by Livy may be hiding another reality: a circumstantial coalition or alliance between native communities.

24 A name constructed from the root sego-, such as Seguntia in book 34.

25 It is one of the names in the turma Salluitana (CIL $\left.\mathrm{I}^{2} 709\right)$.

26 In the third Bronze of Botorrita (Beltrán Lloris et al. 1996, III.31 and III.38).

27 According to Bernardo Stempel $(2013,638)$, the base is Iberian with Celtiberian suffixes, indicating gender; Turtun-az being masculine and Turtun-ta femenine. *Turtun-belis is an Iberian compound name. See also Turtular, inscribed on a dolium in Ensérune (Untermann 1980, B.1.367).

In the province of Guadalajara (Villar 1995, 75-76). 
by the consul, together with the place name Turta (or Turda?). At first, Turdetani designated a community from Citerior, bordering the southern Celtiberians, unrelated to the territories, which would later become part of the Baetica province. In other words, there was no connection with what Strabo called Turdetani and Turdetania. In Books 33-34 of the History of Rome, Livy recovers Cato's names (Turta/Turda, Turdetani, Turdetania), but never uses them to speak of Baetica or any part of it. On the other hand, Livy mistakenly uses the same names Turdetani and Turdetania to designate, in Books 21, 24 and 28, the enemies of Saguntum, whose actions indirectly contributed to the outbreak of the Second Punic War. Fortunately, the real name of the small community in the environs of Saguntum, Torbolêtes, was preserved by Appian, and the name of its capital, Torbola or Turbula, by Ptolemy.

\subsection{Polybius and Appian}

Virtually nothing has been preserved of Polybius' geographical descriptions, which may have mentioned Turdetania. We only know that he differentiated two groups, the Turdetani and the Turduli, the latter to the north of the former. ${ }^{29}$ The brief reference does not mention the geographical positions of these two neighbouring communities. Nevertheless, Strabo (3.2.15) adds some information to Polybius' notion of Turdetania which has not been sufficiently assessed by recent scholarship. When speaking of the civilizing influence exerted by the Turdetani over the Celtici of south-west Iberia, he points out 'vicinity' as the main cause, and mentions that Polybius has a differing opinion, explaining it rather in terms of kinship. Despite its brevity, such an indication opens interesting perspectives. The relationship between Turdetani and Celtici in Polybius echoes half a century later Cato's Turdetani/Celtiberi, suggesting affinities with the central and western Celtic spheres in Hispania, rather than with the coastal Punic world and lower Guadalquivir.

Appian mentions a region called 'Turditania' four times in the book of his Roman History dedicated to Iberia, although with scant geographical data. According to his narrative for the years 212-211 вCE (Hisp. 16), the Carthaginians wintered in Turdetania, while the Romans did so in the mid-Baetis Valley, Gnaeus Cornelius Scipio in Urso (Osuna) and his brother Publius in Castulo. The Turdetania occupied by the Carthaginians could be located more to the south, in the lower Baetis Valley. However, when war resumed the next summer, the Carthaginians attacked Publius Scipio first. Given that Castulo is

29 Strab. 3.1.6. With the loss of Book 34, dealing with geography, we are left without the specifics of the ethnic composition of Polybius' Iberia. On these issues, see the studies compiled in Santos, Torregaray 2003.

For use by the Author only | (c 2019 Koninklijke Brill NV 
located further north, along the Guadalquivir Valley, than Osuna, it is difficult to place the operational base of the Carthaginians in the lower valley of the same river. Subsequently, Turdetania should be sought for outside the valley, to the west or north-west of the positions occupied by the Romans.

The choronym appears again in 151-150 BCE, when Lucullus, governor of Citerior, wintered in Turdetania, after a campaign against the Vaccei in the Durius Valley, while his colleague from Ulterior did so among the Cunei, in south-west Iberia (Hisp. 55, 59). These references are not sufficient to propose a precise location. Shortly after, in 148-147 BCE, Viriathus and the Lusitanians invaded Turdetania, where they attacked the Romans (Hisp. 61). Useful geographical clues may be extracted from the places mentioned by Appian in relation to this attack. The Romans were defeated by Viriathus near Tribola, ${ }^{30}$ taking refuge in a city called Karpêssos, a name clearly linked with Karpêtania, which Viriathus attacked next. This Karpêtania is the Carpetania of the Roman authors, a region populated by Celts of central Hispania, bordering with Celtiberia, whose name derives from the root carp- or carb-.$^{31}$ Playing around with the same suffixes as Appian, Polybius first calls the Carpetanians Karpêsioi, in a book based on Greek sources (3.14.2), and later Karpêtanoi in a passage based on Roman sources (10.7.5). Lastly, the Romans taking refuge in Karpêssos ask for help from the Celtiberian Belloi and Titthoi, who, given the circumstances, could not be far away (Hisp. 63). The pictured scenario is very similar to Cato's campaign in 195 ВСE: a place in the southern Meseta, on this occasion near Carpetania, and the intervention of the Celtiberians from a neighbouring territory. Nevertheless, Appian himself sets the stage for confusion among modern scholarship when, after mentioning Karpêssos, he suggests it was 'a maritime town which I think was formerly called by the Greeks Tartêssos'. Appian warns us that this is a personal interpretation (egô nomizô): in fact, he is the only author to propose such a synonymy. It is probably a mistake, perhaps due to a confusion with the name Carteia, a maritime city near the Strait. In sum, despite his imprecision and incoherencies, Appian allows us to envision a Turdetania that was much more inland than Strabo's, somewhere between Lusitania and Celtiberia.

Lastly, let us recall an entry in the lexicon of Stephanus of Byzantium, who mentions - unfortunately without naming his source - a city called Broutobria, located 'between the Baetis and the Turditanoi', and meaning 'city of Brutus.' ${ }^{32}$

\footnotetext{
$30 \quad$ There are no other references to this city in the ancient sources.

31 The root is also found in the name of the city Contrebia Carbica, known for its coinage and located in Fosos de Bayona (Cuenca), near the frontier between Carpetania and Celtiberia (García Bellido and Blázquez 2001, 2:257). 
This Brutobriga ${ }^{33}$ has not been identified, although coins with this name have been found in Extremadura. ${ }^{34}$ It was probably a foundation of D. Junius Brutus Callaicus, who commanded in Hispania between $138-136$ вСE. If the topographical indications provided by Stephanus are followed, considering that no place name is known in the Guadalquivir Basin with the Celtic suffix -briga, not even in all of southern Andalusia, the only logical option is to search for Turdetania more to the north or to the west, outside the Guadalquivir Valley, between the south-west Meseta and Extremadura. This position is compatible with what is known of the Turdetania of Polybius, ${ }^{35}$ and in any case, it is diametrically opposed to the Turdetania known through Strabo, which makes the Baetis its central axis.

\section{The Turdetanias of the Geographers}

The leading role Strabo awarded Turdetania is well known. It encompassed geographical, economic, cultural and ethnic elements. ${ }^{36}$ The motives behind creating the fiction of such an ideal country remain unclear. According to Strabo, Turdetania was heir to the mythical kingdom of Tartessus, incomparable in terms of its refined civilization and natural resources. Why and how did such a great gap appear between the Turdetania of Cato, Livy and Appian, as has been described above, and the one presented by Strabo?

In a recent paper, ${ }^{37}$ Gonzalo Cruz Andreotti focuses on Strabo's contradictions concerning the limits of Turdetania. After explaining that the territory coincided with the Baetis Basin (3.1.6), Strabo describes various places which are not found in this precise geographical location; some of them did not even belong to the Roman province of Baetica, such as the communities 'beyond the Anas' (3.2.1). In fact, chapters 1 and 2 of Book 3 contain evidence which demonstrates that Strabo, when establishing the limits of Turdetania, wavered between two different geographical representations without clearly deciding which to follow.

33 It is generally agreed that -bria is a corrupted form of the Celtic suffix -briga, well attested in other compound names of the same type (Augustobriga, Caesarobriga).

34 García Bellido and Blázquez 2001, 2: 69.

35 Bouiron $(2014,392)$ attributes the origin of this passage to Polybius. However, the dates for the campaigns of Brutus in Hispania are difficult to match with the dates, in which the Histories of Polybius were written.

36 See Cruz Andreotti 1993 and 2007 (with bibliography), for understanding the complexity of the Strabonian concept of Turdetania in all of its ramifications.

Cruz Andreotti 2007, 257.

For use by the Author only | ( 2019 Koninklijke Brill NV 
The first definition is clear and precise: Turdetania is 'the country through which the Baetis flows' (3.1.6). The same criterion - that of a geographical unit structured by a river - is repeated in 3.2.1 when Strabo says 'it is above the coast this side of the Anas that Turdetania lies, and through it flows the Baetis River' ${ }^{38}$ Turdetania is defined here as a region located inland, a $m e-$ sogaia. ${ }^{39}$ However, contradictions soon appear. In the following sentence, Turdetania is said to reach the sea, between Gades and the Anas. In the line after that, Strabo suggests that the Bastetani, who occupy the coast between Calpe and Gades 'also belong to Turdetania, and so do those Bastetani beyond the Anas'. With this possible extension, Strabo stealthily introduces a second definition, that of an expanded Turdetania, which would include the coast between Cádiz and the Strait, as well as part of the Anas Basin. Although Strabo does not seem very comfortable with this expanded concept, it predominates de facto in the descriptions of chapter 2, when speaking, for example, of the natural riches of the Turdetanian coastlines, which extend to the Pillars (3.2.7). In sum: Strabo doubted between a Turdetania, stricto sensu, limited to the interior of the Baetis Valley and a heterogeneous Turdetania, lato sensu, which included most of the south-western quadrant of Iberia, its civilization and natural riches being the only common denominators (Figure 2.2).

This hesitation could have resulted from Strabo's sources and their divergences. Unfortunately, barely any of the descriptions of Artemidorus or Posidonius have been preserved, the most commonly used authors in Book 3. As for Artemidorus, we only know ${ }^{40}$ that his Geography contained the variants Tourtutania (for the choronym), Tourtoi and Tourtutanoi (for the ethnonym), ${ }^{41}$ hence confirming the spelling used by Cato (Turta) over Livy's Turda, as well as providing a curious version of the ethnonym, with a zero-grade suffix: Tourtoi. His testimony appears, therefore, somewhat archaic, at least in comparison with Strabo's version. On the other hand, absolutely nothing is known of Posidonius' Turdetania. It seems improbable that he did not mention the Turdetani in his work, and many scholars consider Posidonius the main source for Strabo's chapters on Turdetania, although there is not the slightest bit evidence to support such a claim.

38 In two other occasions (3.2.7 and 3.2.15), Strabo relates Turdetania with the river, but not in such an exclusive or specific manner.

39 This word appears further ahead in 3.2.7, associated to Turdetania.

40 The recently published fragments (Gallazzi et al. 2008) of the description of the Iberian coastline do not contain these names.

41 Steph. Byz., s.v. Tourdêtania (cf. Faust 1966, 23).

For use by the Author only | (c 2019 Koninklijke Brill NV 
Besides the Turdetani, Strabo also speaks of the Turduli in three occasions. First, he states 'at the present there is no distinction to be seen' among the Turduli and the Turdetani, despite the differences in opinion existing between his predecessors on this subject (3.1.6). The other two references are more specific. While evoking the name given by ancient authors to the city located in the middle of the Baetis river mouth, he mentions that the surrounding region, which was previously known as Tartesis, was inhabited at his time by the Turduli (3.2.11); and while speaking of the Roman foundations in Hispania, he mentions that Augusta Emerita was founded among the Turduli (3.2.15). Hence, after negating their existence, Strabo, somewhat timidly, decides to maintain the differentiation with the Turduli. More specifically, he divides them into two groups located on the limits of Turdetania, one on the southern Atlantic coast, and the other in the Anas Basin; while reserving the ethnonym Turdetani for the inhabitants of central Baetica, and particularly for 'those that live about the Baetis' (3.2.15). This division of the Turduli into two opposing areas of Turdetania's periphery coincides with Pliny's version, which locates a group of Turduli on the coast, neighbours to the Bastuli, and another between the Baetis and the Anas. ${ }^{42}$ This cannot be a coincidence.

The expansion suggested by Strabo imposes the notion of a Turdetania which derives directly from the decision to equate the Turduli to the Turdetani. However, his description preserves many elements belonging to a more restricted vision: that of a Turdetania located further inland, with groups of Turduli around its periphery. The source for this more limited concept is unknown: Polybius, Posidonius or Artemidorus. It originates no doubt from the Late Hellenistic geographical tradition, which is mainly represented in Strabo's sources by these three authors.

Strabo's concept of the choronym Turdetania does not seem to have earned many followers; he was completely out of phase with the uses of the Roman administration in the Augustan and Julio-Claudian periods. Pliny the Elder, in his Book 3, describes Baetica with radically different choronymic references (Figure 2.3). The names Turdetani and Turdetania are completely absent from Pliny's description and the Turduli he mentions are confined to the periphery of Baetica: the Atlantic coast east of the Anas ( $\mathrm{NH}_{3} 3.8$ ); the limits of Lusitania in Baeturia, between the Baetis and $\mathrm{Anas}^{43}$ ( $N H$ 3.13); without forgetting the

42 On the question of the two Turduli groups (or three if the Duoro Turduli veteres are considered), see Untermann 2004, who defends the idea of a 'chance homophony' between two completely different groups: a Celtic community, spread between the Anas and the Duoro, and another of Tartessian origin, on the southern coast. 


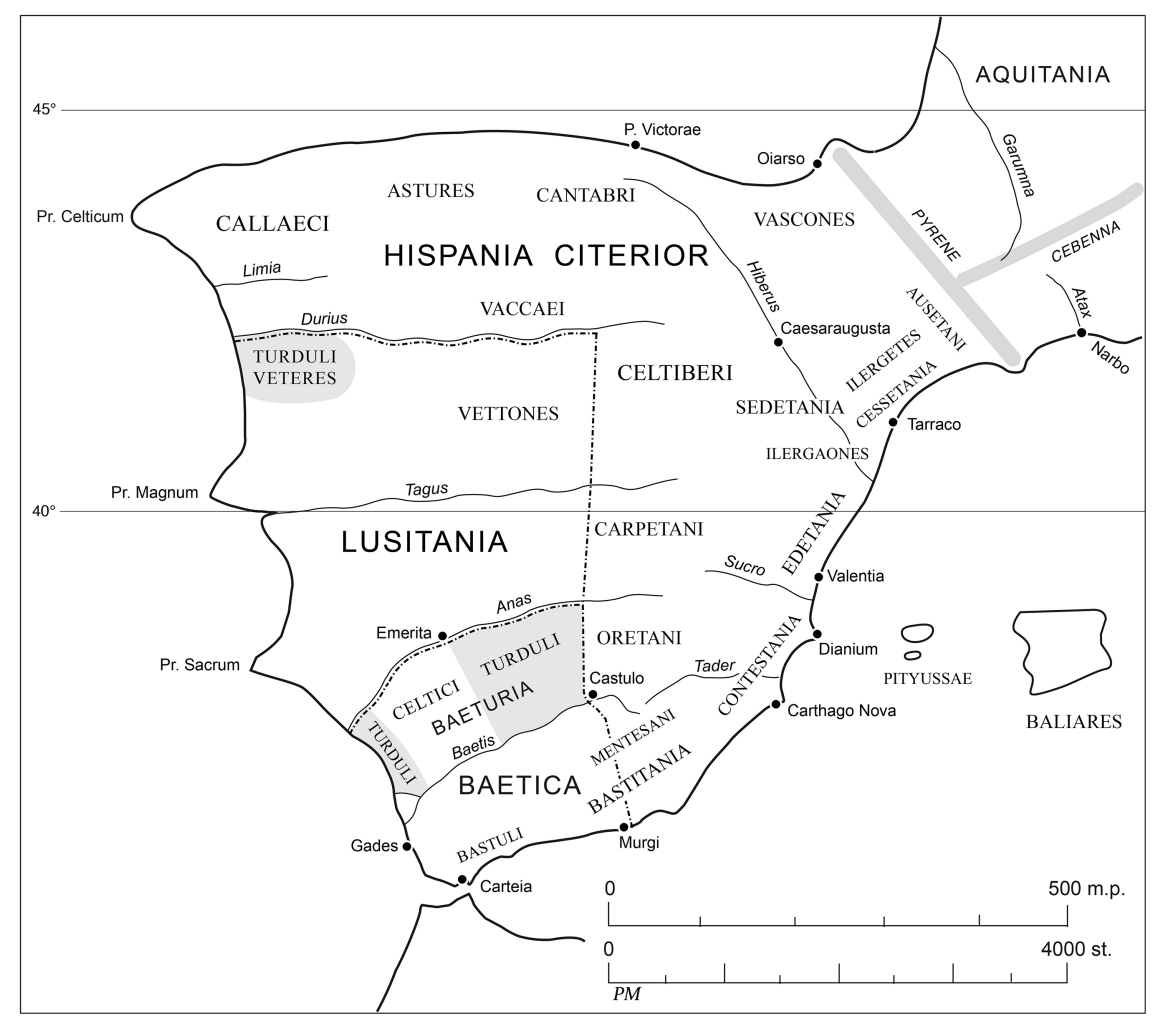

FIGURE 2.3 Baetica and Turduli in Pliny's Hispania.

SHAPE OF HISPANIA AS IN MORET 2016A.

isolated branch of the Turduli veteres north of the Durius ( $N H$ 4.113). For Pliny, the central Baetis Valley was not ethnically defined; there was no other territorial framework than the Roman province of Baetica and its conventus. ${ }^{44}$ The same ethnic division is found in Pomponius Mela, who mentions two groups of Turduli - the Turduli of coastal Baetica (3.3) and the Turduli veteres of the Duoro (3.8) - but ignores Turdetania.

Turdetania appears again in the second century in Ptolemy's map, occupying a very large area - wider than in any other author - which extended over a great part of Baetica and Lusitania: most of the coast between the Guadalquivir and the Sado rivers; towards the interior, the regions 'which border Lusitania' (2.4.10), in the current Extremadura; and the lands 'around the Sacred Promontory' (2.5.4) in the Baixo Alentejo (Figure 2.4). It appears to be the 


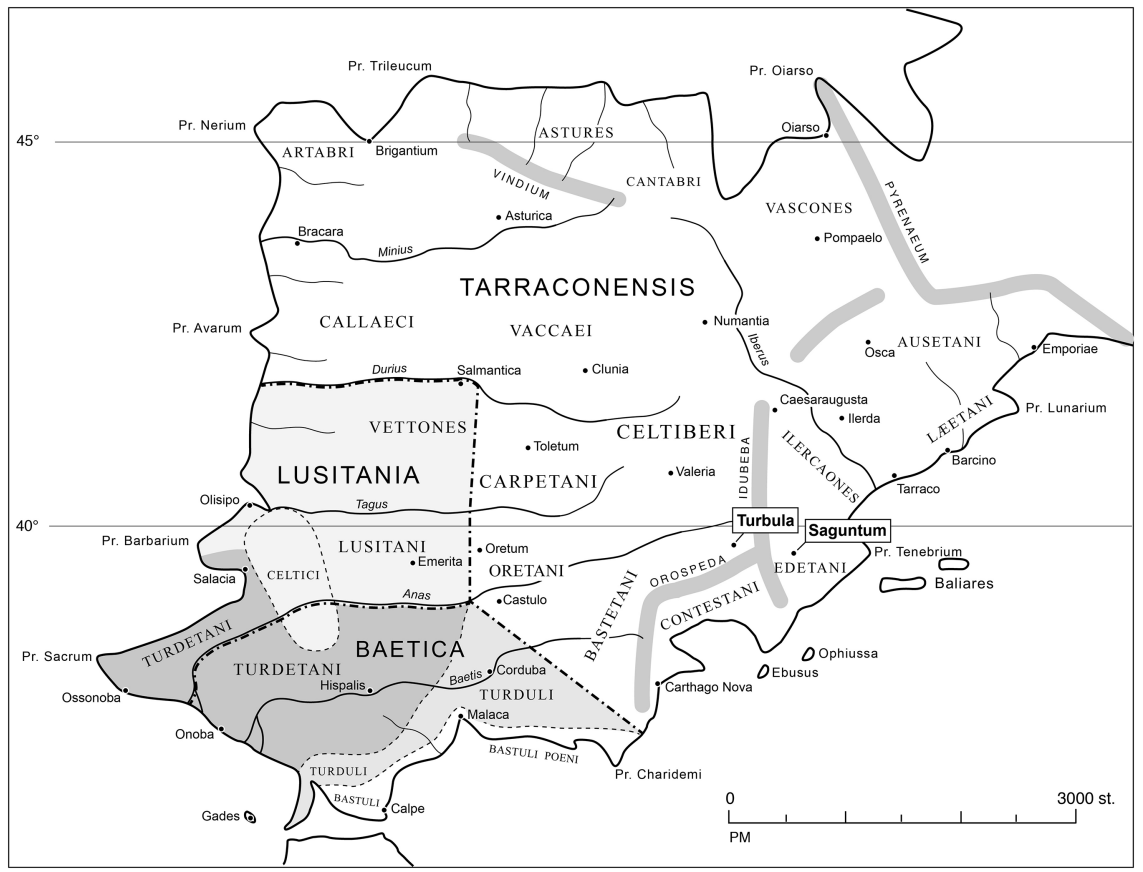

FIgURE 2.4 Turdetania in Ptolemy's Iberia.

SHAPE OF IBERIA AFTER STÜCKELBERGER AND GRASSHOFF 2006.

sum of Strabo's Turdetania, sensu lato, Pliny's Baeturia Turdula, and the region of the Sacred Promontory (current Algarve), which no other author attributes to the Turdetani. Since Ptolemy's sources are unknown, ${ }^{45}$ it is impossible to clarify the genesis of this ethnic-geographic monster. The only certainty is that in Ptolemy's artificial compilation, various Turdetanias may be identified, heirs of different geographical traditions, reflecting different historical moments.

\section{$3 \quad$ How Did the Inhabitants of Baetica Call Themselves?}

In the light of so many contradictions, it is important to consider the name used by the Hispani living in Baetica during the times of Strabo and Pliny, between the end of the first century BCE and the mid-first century CE. The answer is partially found in a recent study, which has revealed that Tartessus was a normal and common form among the Latin speakers and writers of Hispania 
to refer to Cádiz and its environs, while 'Tartessic' or 'Tartessian' was used to describe people and agricultural produce from this region. ${ }^{46}$ This name was not used throughout Baetica, and it is possible that it was reserved for a learned elite. In any case, it remained in use in Strabo's time in a part of the territory, which this author called Turdetanian.

Epigraphy is another source for addressing the question on the selfdenomination of the inhabitants of Baetica. ${ }^{47}$ Early imperial funerary inscriptions sometimes mention an ethnic name in the onomastic formula. Turdetanus/Turdetana is not found among these, although well-known ethnonyms in Hispania include: Bastetanus, Lusitanus, Celtiber, among others. On the other hand, there are six inscriptions mentioning Baeticus/Baetica ${ }^{48}$ and three Turdulus/Turdula. The geographical distribution of these last inscriptions is particularly interesting. One was found in Caurium (Coria, Cáceres), ${ }^{49}$ the other two in Emerita, ${ }^{50}$ which is not surprising, since Strabo (3.2.15) placed Augusta Emerita in the territory of the Turduli, and according to Pliny, the Baeturia of the Turduli bordered on the south with the city of Mérida ( $H N$ 3.13). The Turduli identity found in these three authors is completely disconnected from Strabo's Baetica-Turdetanian conglomerate; it refers, rather, to a Turduli group of Celtic origin, unrelated to the world of the lower Guadalquivir. ${ }^{51}$

When considering the entire history of the development of the name, Strabo appears to be an exception. Among the preserved sources, he is the only one to present Turdetania as a synonym or quasi-synonym for Baetica. Another singularity found in Strabo is his decision to unite Turdetani and Turduli as one entity. On the other hand, there are several points in common among the other authors. Cato, Ptolemy, Polybius, Appian and Mela all consider the Turdetani to be neighbours or kin of the Celtic communities of Hispania (Celtiberians or Celtici), who are located to the north and west of the Baetis Valley. Despite their assumed progressive displacement towards the south-west of Hispania,

46 Álvarez Martí-Aguilar 2007.

47 On this issue, see Le Roux 2007, 200.

48 Abascal Palazón 1994, 297.

49 Hispania Epigraphica 8, 1998, no. 76.

50 CIL II, 523; Hispania Epigraphica 8, 1998, no. 28.

$5^{1}$ Untermann 2004, 206, bases his claim on the Celtic elements found in the onomastic formula of the two Turdulus from Mérida.

For use by the Author only | (c 2019 Koninklijke Brill NV 
TABLE 2.1 Use of the names Tartessus, Turdetani and Turduli in Greek and Latin authors, between the Second Punic War and the Flavian period. The asterisk marks authors born in Iberia or who visited the Peninsula.

\begin{tabular}{|c|c|c|c|}
\hline & $\begin{array}{l}\text { Tartessus } \\
\text { (past } \\
\text { reality) }\end{array}$ & $\begin{array}{l}\text { Tartessus } \\
\text { (contemporary } \\
\text { reality) }\end{array}$ & Turdetani/Turduli \\
\hline Cato* & - & - & Turta, Turdetania \\
\hline Livy & - & Tartesii & $\begin{array}{l}\text { Turdetani, } \\
\text { Turdetania }\end{array}$ \\
\hline Diodorus Siculus & - & Tartêssioi & - \\
\hline Appian & Tartêssos & - & Turditania \\
\hline Polybius* & $?$ & $?$ & $\begin{array}{l}\text { Tourdouloi, } \\
\text { Tourdêtanoi }\end{array}$ \\
\hline Artemidorus* & $?$ & $?$ & Tourtoi, Tourtutanoi \\
\hline Posidonius* & $?$ & $?$ & $?$ \\
\hline Strabo & Tartêssos & - & $\begin{array}{l}\text { Tourdouloi, } \\
\text { Tourdêtanoi }\end{array}$ \\
\hline Ptolemy & - & - & $\begin{array}{l}\text { Tourdouloi, } \\
\text { Tourdêtanoi }\end{array}$ \\
\hline Varro* & - & murena Tartesia & Turduli \\
\hline Cicero & - & Tartessicus (Balbus) & - \\
\hline Pliny* & - & Tartesus & Turduli \\
\hline Pomponius Mela* & - & Tartesus & Turduli \\
\hline Columella* & - & Tartesus, Tartesis & - \\
\hline Martial* & - & Tartesius & - \\
\hline
\end{tabular}

they never settled Baetica, stricto sensu (or, in the case of Ptolemy, not entirely). Furthermore, as of Polybius, there exists a clear separation between Turduli and Turdetani.

Associations become clearer when considering in parallel the history of two names: Tartessus and Turdetania (Table 2.1). Three groups of authors are differentiated. The historians of the Second Punic War and the initial phases of conquest comprise the most complex group, due to the diversity of their sources (pro-Roman or pro-Punic, in Latin or in Greek) and to the formative state of Iberia's choronyms at the time. It is surprising that authors, such as Livy or Diodorus, use Tartesii or Tartêssioi as a contemporary ethnonym, ascribing

\section{For use by the Author only | ( 2019 Koninklijke Brill NV}




\begin{tabular}{|c|c|c|c|}
\hline & TARTESSUS & \multicolumn{2}{|c|}{ TURDETANI / TURDULI } \\
\hline 1- Local name & $?$ & Turta / Turda & $?$ \\
\hline $\begin{array}{l}\text { 2- Greek / latin } \\
\text { adaptation and } \\
\text { exogenous } \\
\text { construction }\end{array}$ & $\begin{array}{l}\text { Tartêssos } \\
\text { Hecataeus, } \\
\text { Herodotus, } \\
\text { Strabo, } \\
\text { Avienus }\end{array}$ & $\begin{array}{l}\text { Turdetani 4... } \\
\text { (SE Meseta) } \\
\text { Cato, Livy } \\
\text { Tourdêtania } \\
\text { (= Baetica) } \\
\text { Strabo, Ptolemy }\end{array}$ & $\begin{array}{l}\text { Turduli } \\
\text { (vicinity of Lusitania) } \\
\text { Varro?, Pliny, Mela } \\
\text { | }\end{array}$ \\
\hline $\begin{array}{l}\text { 3- Recovery by } \\
\text { romanized } \\
\text { Hispani }\end{array}$ & $\begin{array}{l}\text { Tartesus } \\
\text { Columella, } \\
\text { Pliny, Martial }\end{array}$ & & $\begin{array}{l}\text { Turdulus as origo } \\
\text { (inscriptions in the vicinity } \\
\text { of Emerita Augusta) }\end{array}$ \\
\hline
\end{tabular}

FIGURE 2.5 Parallel evolution of names Tartessus and Turdetania names. BY PIERRE MORET.

the name to a real community involved in the confrontations of the Second Punic War. Greek geographers (and historians who dedicated large sections of their work to geographical descriptions) make up the second group. They consistently mention a community called Tourdêtanoi or Tourtutanoi, although never the choronym Tartêssos in reference to a present geographical reality in Iberia. Finally, the third group is made up of the Latin authors, who best knew Hispania. For them, Tartessus always corresponds to a contemporary reality, not to a mythical past and they never speak of Turdetani.

Figure 2.5 organizes the same data, distinguishing three main phases for the evolution of an ethnonym in any context of conquest or domination of a territory by a foreign power. The initial phase, not documented here, belongs to the pre-existing indigenous ethnonym. The second phase adapts the name to the phonology, morphology and semantics of the conquering language, an adaptation, which is accompanied by a process of exogenous ethnographic construction (of literary or political motivation). In the last phase, the transformed name is reappropriated by an acculturated indigenous elite, which may or may not be heir to the primitive users of the name. This phase exists for the name Turduli, but not for Turdetani and Turdetania.

In fact, Turdetania, as a choronym and an ethnonym, fell into disuse as of the early first century в ве, both among the population of southern Iberia and the Roman administrators of the province, and only survived as part of a relatively marginal, and perhaps anachronic, geographical tradition, only 
detected in foreign authors who wrote in Greek, such as Artemidorus or Strabo, and as a final echo, divorced from all contemporary reality, in Ptolemy. During the same period, and well into the first century CE, the Latin sources, following the uses of Gaditanian learned elites, called this region Baetica or Tarte(s)sus, and its inhabitants Baetici or Tarte(s)sii, never Turdetania and Turdetani.

In sum, through the analysis of the texts of Livy and Cato, it is possible to affirm that the community called Turdetani by the Romans at the beginning of the conquest of Iberia was situated in or near the southern Meseta. During the second half of the second century вСЕ, it was displaced to the south-west by authors such as Polybius and the sources of Appian, although it is not possible to assert that these Turdetani were the same ones as Cato's. The place assigned to Turdetania in Strabo's geographical construction radically differs from the locations described by other historians, as well as from the use the name was given by the Roman administration, as reflected in Pliny, who only mentions Baetica and its conventus, and finally, also from the contemporary practice of the locals, who identified themselves as Baetici or Turduli, yet never as Turdetani.

Nevertheless, modern scholarship adopted without critique Strabo's point of view. The first consequence of this choice was the consolidation and almost universal assumption of an old etymological speculation, ${ }^{52}$ which defends a close kinship between the names Turdetani, Thersitai, Tartessos and Tarshish. ${ }^{53}$ From a strictly morphological point of view, the inclusion of Turdetani in this series poses problems. In order to justify a relationship with Tarshish and Tartês-(os), scholars have wanted to see the root Turdet- followed by a Latin desinence -anus, ${ }^{54}$ whereas the only acceptable way to analyse the name, from the Latin context of its suffix, is $\operatorname{Turd}(a)+$-etani / -etania. ${ }^{55}$ This linguistic hypothesis has led many authors to defend the existence of a direct ethnic affiliation between Tartessians and Turdetanians. ${ }^{56}$ Another, more recent, consequence is the choice of the adjective Turdetanian to designate, from an

$5^{2} \quad$ Movers 1850, 603-4 and 612; other references in Koch 1984 (=2003).

53 This is the central thesis of Koch 1984, followed by García Moreno 1989 and Lipinski 2004.

54 Movers 1850, 612; Lenormant 1868, 2: 292; Lipinski 2004, 251: 'the alternative forms Tartes(sus) and Turdet(ani) reflect various perceptions and adaptations of the native Iberian pronunciation'.

55 Faust 1966, 21-22. Among other arguments, Faust notes that the word game introduced by Plautus in the Captivi (Turdetani / turdus) could only work if the Roman public of the 19os understood-etani as a suffix.

$5^{6}$ For the current state of affairs, with bibliography, García Fernández 2003.

For use by the Author only | (c 2019 Koninklijke Brill NV 
archaeological point of view, everything belonging to the Late Iron Age in lower Andalusia. ${ }^{57}$ Such a scenario becomes problematic and blurred once the geographical relationship of the Turdetanians with the lower Guadalquivir and their genetic link to the Tartessians is broken, exposed as an artificial construction of Late Hellenistic geography, without any real basis in the society or territorial organization of Republican and Early Imperial Hispania.

57 From different points of view, and among many other possible references: Escacena 1989, Ruiz Mata 1998, Ferrer Albelda and García Fernández 2002. 